\title{
Penerapan Strategi Pembelajaran Time Token untuk Meningkatkan Hasil Belajar Siswa Mata Pelajaran IPS Kelas V MI Miftahul Huda Lamongan
}

\author{
WAHIDAH PUSPA DINA \\ Program Studi Pendidikan Guru Madrasah Ibtidaiyah \\ Fakultas Agama Islam Universitas Islam Lamongan \\ E-mail : wahidah.puspa.dina70@gmail.com
}

\begin{abstract}
ABSTRAK:
Penelitian Tindakan Kelas (PTK) ini dilatarbelakangi oleh rendahnya hasil belajar siswa kelas V MIwMiftahul Huda pada mata pelajaran IPS. Dari 11 siswa keseluruhan 6 dinyatakan tidak tuntas dalam ulangan harian. Oleh karena itu perlu diterapkan strategi yang dinilai dapat meningkatkan hasil belajar siswa, salah satu strategi tersebut adalah strategi time token. Strategi time token dinilai tepat karena mempunyai banyak kelebihan dan sesuai dengan karakteristik siswa. Tujuan penelitian ini yaitu untuk mengetahui penerapan strategi pembelajaran time token dalam meningkatkan hasil belajar siswa dalam mata pelajaran IPS dan untuk mengetahui peningkatan hasil belajar siswa-siswi dalam pembelajaran IPS. Penelitian ini menggunakan metode penelitian Kurt Lewin yang terdiri atas dua siklus. PTK ini dapat dikatakan berhasil jika; 1) Sebanyak 90\% siswa atau lebih termasuk dalam kategori tuntas, 2) Kriteria Ketuntasan Minimal (KKM) mata pelajaran IPS kelas V yaitu sebesar 75, dan 3) Guru dapat melaksanakan proses pembelajaran sesuai rencana pembelajaran sebesar $85 \%$. Dari kriteria ketuntasan tersebut, pembelajaran dengan menerapkan strategi pembelajaran time token dinyatakan dapat meningkatkan hasil belajar siswa kelas V MI Miftahul Huda pada mata pelajaran IPS. Hal ini dapat dilihat dari peningkatan nilai siswa pada siklus 1 nilai rata-rata siswa sebesar 72 dengan persentase ketuntasan sebesar 64\% meningkat pada siklus II sebesar 83 dengan 91\%. Hasil observasi guru dalam kegiatan pembelajaran pada siklus I sebesar $72 \%$ mengalami peningkatan pada siklus II sebesar 91\%. Selain itu dilihat dari hasil observasi aktivitas siswa pada siklus I dengan persentase sebesar $64 \%$ mengalami peningkatan pada siklus II sebesar $80 \%$.
\end{abstract}

Kata Kunci : Strategi Time Token, Hasil Belajar IPS, Penelitian Tindakan Kelas.

\section{Pendahuluan}

Secara bahasa, strategi bisa diartikan sebagai siasat, kiat, trik, atau cara. Sedang secara umum, strategi mempunyai pengertian suatu garis-garis besar haluan untuk bertindak dalam usaha mencapai sasaran yang telah ditentukan.
Dihubung-kan dengan belajar mengajar, strategi bisa diartikan sebagai pola-pola umum kegiatan guru dan anak didik dalam perwujudan kegiatan belajar 
mengajar untuk mencapai tujuan yang telah digariskan. ${ }^{1}$

Didalam dunia pendidikan strategi diartikan sebagai "a plan, method, or series of activities designed to achieves a particular education goal". Jadi strategi pembelajaran dapat diartikan sebagai perencanaan yang berisi tentang rangkaian kegiatan yang didesain untuk mencapai tujuan pendidikan tertentu. Menurut Wina Sanjaya istilah strategi, sebagaimana banyak istilah lainnya, dipakai dalam banyak konteks dengan makna yang tidak selalu sama. Di dalam konteks belajar mengajar, strategi berarti pola umum aktivitas guru-peserta didik dalam perwujudan kegiatan belajar mengajar. Sifat umum pola tersebut berarti bahwa macam dan urutan perbuatan yang dimaksud tampak dipergunakan gurupeserta didik di dalam bermacam-macam peristiwa belajar. $^{2}$

Sedangkan kata pembelajaran merupakan perpaduan dari dua aktivitas belajar dan mengajar. Aktivitas belajar secara metodologis cenderung lebih dominan pada siswa, sementara mengajar secara instruksional dilakukan oleh guru. Jadi, istilah pembelajaran adalah ringkasan dari kata belajar dan mengajar. Dengan kata lain, pembelajaran adalah penyederhanaan dari kata belajar dan mengajar (BM), proses belajar mengajar (PBM), atau kegiatan belajar mengajar $(\mathrm{KBM}){ }^{3}$

1 Hamruni, strategi pembelajaran, Yogyakarta:Insan Madani, 2012, hlm 1

2 Hamruni, strategi pembelajaran,... hal 1-2

3 Ahmad Susanto, Teori belajar dan pembelajaran di sekolah dasar, Jakarta:Kencana, 2013, hlm 18-19
Kata atau istilah pembelajaran dan penggunaannya masih tergolong baru, yang mulai populer semenjak lahirnya Undang-Undang Sistem Pendidikan Nasional No.20 Tahun 2003. Menurut undang-undang ini pembelajaran diartikan sebagai pola interaksi peserta didik dengan pendidik dan sumber belajar pada suatu lingkungan belajar. Menurut pengertian ini, pembelajaran merupakan bantuan yang diberikan pendidik agar terjadi proses perolehan ilmu dan pengetahuan, penguasaan, kemahiran dan tabiat, serta pembentukan sikap dan keyakinan pada peserta didik. Dengan kata lain, pembelajaran adalah proses untuk membantu peserta didik agar dapat belajar dengan baik. Namun dalam implementasi-nya, sering kali kata pembelajaran ini diidentikkan dengan kata mengajar. ${ }^{4}$

Pembelajaran yang diidentikkan dengan kata "mengajar" berasal dari kata dasar "ajar" yang berarti petunjuk yang diberikan kepada orang supaya diketahui. Kata pembelajaran yang semula diambil dari kata "ajar" ditambah awalan "pe" dan akhiran "an" menjadi kata "pembelajaran", diartikan sebagai proses, perbuatan, cara mengajar, atau mengajarkan sehingga anak didik mau belajar. ${ }^{5}$

Jadi pembelajaran merupakan proses belajar mengajar yang dilakukan oleh pendidik atau guru dan peserta didik atau siswa dalam rangka untuk mencapai tujuan tertentu yaitu agar anak

\footnotetext{
4 Ahmad Susanto, Teori belajar dan pembelajaran di sekolah dasar, ... hal 19

5 Ahmad Susanto, Teori belajar dan pembelajaran di sekolah dasar, Jakarta:Kencana, 2013, hlm.19
} 
memperoleh baik ilmu pengetahuan, kemahiran atau keterampilan serta sikap atau tabiat yang baik. Sehingga strategi pembelajaran dapat diartikan sebagai perencanaan yang berisi tentang rangkaian kegiatan yang didesain untuk mencapai tujuan pendidikan tertentu. ${ }^{6}$

Strategi pembelajaran dan metode pembelajaran adalah dua hal yang saling berkaitan. Strategi pembelajaran merupakan suatu perencanaan dalam pelaksanaan pembelajaran. Sedangkan metode pembelajaran adalah cara pembentukan atau pengertian peserta (penerima informasi) terhadap suatu penyajian informasi/bahan ajar. Terdapat tiga syarat utama berlangsungnya kegiatan belajar mengajar. Pertama adalah siswa yang berperan sebagai penerima informasi, kedua adalah materi bahan yang akan disampaikan dan yang ketiga adalah pengajar selaku pengantar dan penyampai bahan ajar. ${ }^{7}$

Secara umum metode diartikan sebagai cara melakukan sesuatu. Secara khusus metode pembelajaran diartikan sebagai cara atau pola yang khas dalam memanfaatkan berbagai prinsip dasar pendidikan. Selain itu, metode juga merupakan berbagai teknik dan sumber daya terkait lainnya agar terjadi proses pembelajaran pada diri pembelajar. ${ }^{8}$

\footnotetext{
6 Hamruni, strategi pembelajaran. Yogyakarta: Insan Madani, 2012, hlm.2

7 Daryanto, Strategi dan Tahapan Mengajar, Bandung:Yrama Widya, 2013, hlm 1

8 Zainal aqib, Model-model, Media dan Strategi Pembelajaran Kontekstual Inovatif, Bandung: Yrama Widya, 2013, hlm 102
}

\begin{tabular}{lcc}
\multicolumn{1}{c}{ Jadi } & strategi & pembelajaran \\
merupakan & suatu & perencanaan \\
pembelajaran & yang dilaksanakan dan \\
disampaikan & kepada peserta didik \\
dengan metode pembelajaran.
\end{tabular}

Kozma (1989) secara umum menjelaskan bahwa strategi pembelajaran dapat diartikan sebagai setiap kegiatan yang dipilih, yaitu yang dapat memberikan fasilitas atau bantuan kepada peserta didik menunju tercapainya tujuan pembelajaran tertentu.9

Selain itu Kemp (1995) juga menjelaskan bahwa strategi pembelajaran adalah suatu kegiatan pembelajaran yang harus dikerjakan guru dan peserta didik agar tujuan pembelajaran dapat dicapai secara efektif dan efisien. ${ }^{10}$ Sehingga menurut uraian diatas strategi pembelajaran merupakan komponen yang penting dalam pembelajaran agar hasil belajar yang diinginkan bisa tercapai.

Secara sederhana, yang dimaksud dengan hasil belajar siswa adalah kemampuan yang diperoleh anak setelah melalui kegiatan belajar. ${ }^{11}$ Untuk mengetahui apakah hasil belajar yang dicapai telah sesuai dengan tujuan yang dikehendaki dapat diketahui melalui evaluasi. Sebagaimana dikemukakan oleh

9 Zainal Aqib, Model-model,Media dan Strategi Pembelajaran Kontekstual inovatif, Bandung: Yrama Widya, 2013,hlm.

10 Wina Sanjaya, Strategi Pembelajaran Berorientasi pada standar proses pendidikan, Jakarta: Kencana, 2006, hlm. 126

11 Ahmad Susanto, Teori belajar dan pembelajaran di sekolah dasar, Jakarta: Kencana, 2013, hlm.5 
Sunal (1993:94), bahwa evaluasi merupakan proses penggunaan informasi untuk membuat pertimbangan seberapa efektif suatu program telah memenuhi kebutuhan siswa. ${ }^{12}$

Jadi hasil belajar yang akan ditingkatkan tidak hanya berupa nilai tes siswa tetapi juga tingkat motivasi belajar siswa dilihat dari aktivitas siswa saat pembelajaran.

Seorang guru yang ingin hasil belajar siswanya baik maka harus menggunakan strategi pembelajaran yang tepat. Jika strategi yang digunakan tidak tepat, maka hasil belajar yang ingin dicapai tidak akan terpenuhi. Tetapi faktanya, masih banyak guru yang menggunakan strategi konvensional. Strategi tersebut menempat-kan siswa sebagai objek. Sehingga yang aktif dalam pembelajaran hanyalah guru dan hasil belajar siswa yang ingin dicapai dalam suatu mata pelajaran tidak akan terpenuhi.

Salah satu mata pelajaran yang paling sering menggunakan strategi konvensional adalah IPS. Karena hampir semua materinya adalah hafalan. IPS merupakan bagian dari kurikulum sekolah yang diturunkan dari isi materi cabang-cabang ilmu sosial seperti sosiologi, sejarah, geografi, ekonomi, politik, antropologi, filsafat dan psikologi sosial. $^{13}$

Tujuan pendidikan IPS pada dasarnya untuk mendidik dan memberi bekal kemampuan dasar kepada siswa untuk mengembangkan diri sesuai bakat,

12 Ahmad Susanto, Teori belajar dan pembelajaran di sekolah dasar..., hlm. 5

13 Trianto,Model Pembelajaran Terpadu, Jakarta: Bumi Aksara, 2010, hlm 78 minat, kemampuan dan lingkungannya, serta berbagai bekal bagi siswa untuk melanjutkan pendidikan ke jenjang yang lebih tinggi. ${ }^{14}$

Salah satu sekolah dasar yang masih menggunakan strategi konvensional dalam pembelajaran IPS adalah MI Miftahul Huda Lamongan. Karena gurunya menggunakan strategi pembelajaran konvensional atau kurang variatif, maka hasil belajar peserta didiknya kurang memuaskan. Hal ini bisa dilihat dari hasil ulangan harian siswa kelas $\mathrm{V}$ pada mata pelajaran IPS materi peristiwa sekitar proklamasi, 6 dari 11 siswa nilainya dibawah KKM (Kriteria Ketuntasan Minimal). KKM mata pelajaran IPS di MI Miftahul Huda yaitu 75. Karena itu perlu diadakannya penelitian untuk meningkatkan hasil belajarnya.

Ada berbagai strategi pembelajaran yang dapat digunakan dalam pembelajarn IPS materi sekitar proklamasi, antara lain; TPS (Think Pair Share), demonstrasi, dan time token. Strategi TPS dan demonstrasi kurang sesuai karena tidak sesuai dengan karakteristik siswa yang pasif. Jadi dipilihlah strategi pembelajaran time token yang paling sesuai dengan karakteristik siswa. Strategi pembelajaran Time Token merupakan salah satu contoh kecil dari penerapan pembelajaran demokratis di sekolah. Proses pembelajaran yang demokratis adalah proses belajar yang menempatkan siswa sebagai subjek. Sepanjang proses belajar, aktivitas siswa menjadi titik perhatian

14 Etin, Solihatin, Cooperative Learning, Jakarta: Bumi Aksara, 2007, hlm 23 
utama. Dengan kata lain mereka selalu dilibatkan secara aktif. Guru berperan mengajak siswa mencari solusi bersama terhadap permasalahan yang ditemui. ${ }^{15}$

Selain itu strategi time token mempunyai banyak kelebihan antara lain; 1) mendorong siswa untuk meningkatkan inisiatif dan partisipasi; 2) menghindari dominasi siswa yang pandai berbicara atau yang tidak berbicara sama sekali; 3) membantu siswa untuk aktif dalam kegiatan pembelajaran; 4) meningkatkan kemampuan siswa dalam berkomunikasi (aspek berbicara); 5) melatih siswa untuk mengungkapkan pendapat; 6) menumbuh-kan kebiasaan pada siswa untuk saling mendengarkan, berbagi, memberikan masukan, dan memiliki sikap keterbukaan terhadap kritik; 7) mengajarkan siswa untuk menghargai pendapat orang lain; 8) mengajak siswa mencari solusi bersama terhadap permasalahan yang dihadapi; dan 9) tidak memerlukan banyak media pembelajaran. ${ }^{16}$

Adapun sintak dari strategi pembelajaran time token ini dalam Huda (2013) adalah sebagai berikut; 1) Guru menjelaskan tujuan pembelajaran atau kompetensi dasar, 2) Guru mengondisikan kelas untuk melaksanakan kondisi klasikal, 3) Guru memberi tugas pada siswa untuk memahami bacaan yang diberikan oleh guru mengenai materi pembelajaran 4)

15 Miftahul Huda, Model-model Pengajaran dan Pembelajaran, Yogyakarta: Pustaka Pelajar, 2013, hlm 241

16 Miftahul Huda, Model-model Pengajaran dan Pembelajaran ... hlm 241
Guru memberi sejumlah kupon berbicara dengan waktu \pm 30 detik per kupon pada tiap siswa, 5) Guru meminta siswa menyerahkan kupon terlebih dahulu sebelum berbicara atau memberi komentar. Satu kupon untuk satu kesempatan berbicara. Siswa dapat tampil lagi setelah bergiliran dengan siswa lainnya. Siswa yang telah habis kuponnya tidak boleh bicara lagi. Siswa yang masih memegang kupon harus berbicara sampai kuponnya habis. Demikian seterusnya hingga semua anak berbicara, 6) Guru memberi sejumlah nilai berdasarkan waktu yang digunakan tiap siswa dalam berbicara. ${ }^{17}$

Sebelum melaksanakan penelitian, indikator kinerja atau kriteria yang akan dicapai harus jelas. Indikator kinerja dalam Kunandar (2011) adalah suatu kriteria yang digunakan untuk melihat tingkat keberhasilan dari kegiatan PTK dalam meningkatkan atau memperbaiki KBM di kelas. ${ }^{18}$

Indikator kinerja PTK ini antara lain; 1) Sebanyak $90 \%$ siswa atau lebih termasuk dalam kategori tuntas.; 2) KKM mata pelajaran IPS kelas V MI yaitu sebesar 75. 3) Guru dapat melaksanakan proses pembelajaran sesuai rencana pembelajaran sebesar $85 \%$.

Dari uraian di atas dapat dirumuskan permasalahan sebagai berikut: 1) Bagaimana penerapan strategi pembel-

17 Miftahul Huda, Model-model Pengajaran dan Pembelajaran, Yogyakarta: Pustaka Pelajar, 2013, hlm 241

18 Kunandar, Langkah-langkah Penelitian Tindakan Kelas, Jakarta : Raja Grafindo Persada, 2011, hlm. 127 
ajaran time token dalam pembelajaran mata pelajaran IPS kelas V MI Miftahul Huda?; 2) Bagaimana peningkatan hasil belajar siswa kelas V MI Miftahul Huda dalam pembelajaran IPS dengan penerapan strategi pembelajaran time token?.

Berdasarkan rumusan masalah diatas, tindakan yang dipilih dalam penelitian tindakan kelas ini yaitu dengan menggunakan strategi pembelajaran time token. Dengan menggunakan strategi pembelajaran ini diharapkan dalam pembelajaran IPS siswa-siswi kelas V MI Miftahul Huda hasil belajarnya lebih meningkat lebih memuaskan.

Penelitian ini terbagi menjadi dua siklus, setiap siklus dilaksanakan berdasarkan model Kurt Lewin yakni mengikuti prosedur perencanaan (planning), tindakan (acting), pengamatan (observing), dan refleksi (reflecting). Melalui dua siklus tersebut dapat diamati peningkatan hasil belajar siswa sebagai berikut "Dengan diterapkan strategi pembelajaran time token dalam proses pembelajaran IPS dapat meningkatkan hasil belajar siswa-siswi kelas V MI Miftahul Huda".

Sesuai rumusan masalah dan tindakan yang telah ditentukan, maka tujuan yang ingin dicapai dalam penelitian tindakan kelas ini adalah; 1) Untuk mengetahui penggunaan strategi pembelajaran time token dalam meningkatkan hasil belajar siswa dalam mata pelajaran IPS.; 2) Untuk mengetahui peningkatan hasil belajar siswa-siswi dalam pembelajaran IPS dengan menggunakan strategi pembel-ajaran time token.

\section{Metode}

Penelitian ini merupakan Penelitian Tindakan Kelas (PTK). PTK adalah proses pengkajian masalah pembelajaran di dalam kelas melalui refleksi diri dan upaya untuk memecahkannya dengan cara melakukan berbagai tindakan yang terencana dalam situasi nyata serta menganalisis setiap pengaruh dari tindakan tersebut. ${ }^{19}$

Model penelitian yang digunakan dalam PTK ini yaitu model Kurt Lewin. Kurt Lewin menjelaskan bahwa ada empat hal yang harus dilakukan dalam proses penelitian tindakan yakni perencanaan, tindakan, observasi dan refleksi. Pelaksanaan penelitian tindakan adalah proses yang terjadi dalam suatu lingkaran yang terus-menerus. ${ }^{20}$

Perencanaan adalah menentukan program perbaikan yang berangkat dari suatu ide gagasan peneliti; sedangkan tindakan adalah perlakuan yang dilaksanakan oleh peneliti sesuai dengan perencanaan yang telah disusun oleh peneliti. Observasi adalah pengamatan yang dilakukan untuk mengetahui efektivitas tindakan atau mengumpulkan informasi tentang berbagai kelemahan (kekurangan) tindakan yang telah dilakukan dan refleksi adalah kegiatan analisis tentang hasil observasi hingga 
memunculkan program atau perencanaan baru. ${ }^{21}$

PTK ini dilaksanakan dalam dua siklus. Siklus 1 terdiri atas perencanaan, pelaksanaan, pengamatan dan refleksi. Dalam proses perencanaan yang dilakukan adalah: 1) Melakukan analisis kurikulum untuk menentukan standar kompetensi dan kompetensi dasar yang akan disampaikan kepada siswa dengan menggunakan strategi pembelajaran time token; 2) Membuat rencana pembelajaran dengan menggunakan strategi pembelajaran time token 3) Membuat media kupon berbicara; 3) Membuat lembar kerja siswa untuk mengetahui peningkatan hasil belajar siswa setelah melaksanakan pembelajaran dengan menggunakan metode time token; 4) Membuat instrumen yang digunakan dalam siklus PTK yaitu instrumen observasi pelaksanaan mengajar guru di dalam kelas dan instrumen observasi aktivitas siswa dalam proses pembelajaran.

Dalam proses pelaksanaan yang dilakukan adalah: 1) Guru membagi siswa menjadi tiga kelompok; 2) Setiap siswa diberikan beberapa kupon berbicara; beserta materi yang akan dibahas dalam proses pembelajaran; 3) Siswa yang mendapat kupon berbicara diminta menjelaskan salah satu materi pelajaran tanpa melihat teks bacaan; 4) Setiap siswa dalam kelompok menjelaskan salah satu materi pelajaran tanpa melihat teks bacaan secara bergantian; 5) Setiap siswa harus

\footnotetext{
${ }^{21}$ Wina Sanjaya, Penelitian Pendidikan, ... hlm 154
}

menjelaskan salah satu materi pelajaran sampai kupon yang diberikan habis. 6) Setiap siswa diberikan lembar kerja yang digunakan untuk mengetahui peningkatan hasil belajar siswa setelah melaksanakan pembelajaran dengan menggunakan strategi time token.

Dalam proses pengamatan ada beberapa hal yang diamati dalam proses pembelajaran dengan menggunakan instrumen observasi pada siklus I yaitu: 1) pelaksanaan mengajar guru di dalam kelas; 2) aktivitas siswa dalam proses pembelajaran.

Dalam tahap refleksi dan perencanaan ulang (replaning), guru dan peneliti atau pengamat mengevaluasi tingkat keberhasilan pembelajaran yang telah dilakukan. Pada tahap ini hasil observasi guru dan siswa dianalisa dan dicari kekurangannya. Setelah mengetahui kekurangan atau kelemahan pada pembelajaran siklus I maka bisa dilakukan perbaikan yang akan dilaksanakan pada siklus selanjutnya.

Seperti halnya siklus 1 dan siklus 2 dalam PTK ini juga terdiri atas perencanaan, pelaksanaan, pengamatan dan refleksi. berdasarkan replaning dari siklus 1, planing siklus 2 yaitu: 1) membuat rencana pembelajaran dengan mengguna-kan strategi pembelajaran time token; 2) membuat media kupon berbicara; 3) membuat lembar kerja siswa untuk mengetahui peningkatan hasil belajar siswa setelah melaksanakan pembelajaran dengan menggunakan metode time token; 4) Membuat instrumen yang digunakan dalam siklus PTK yaitu 
instrumen observasi pelaksanaan mengajar guru di dalam kelas dan instrumen observasi aktivitas siswa dalam proses pembelajaran.

Dalam pelaksanaan guru membagi siswa menjadi tiga kelompok. Setiap siswa diberikan beberapa kupon berbicara, beserta materi yang akan dibahas dalam proses pembelajaran. Siswa yang mendapat kupon berbicara diminta menjelaskan salah satu materi pelajaran tanpa melihat teks bacaan. Setiap siswa melakukannya secara bergantian sampai kupon yang diberikan habis. Setelah itu setiap siswa diberikan lembar kerja yang digunakan untuk mengetahui peningkatan hasil belajar siswa setelah melaksanakan pembelajaran dengan menggunakan metode time token.

Hasil observasi pembelajaran IPS dengan menggunakan strategi pembelajaran time token pada siklus II diharapkan memperoleh hasil yang maaksimal, banyak siswa yang antusias dan memperhatikan dalam proses pembelajaran.

Beberapa hal yang diamati dalam proses pembelajaran IPS di kelas V MI Miftahul Huda dengan menggunakan instrumen observasi pada siklus I yaitu: 1) pelaksanaan mengajar guru di dalam kelas; 2) aktivitas siswa dalam proses pembelajaran.

Dalam tahap refleksi guru dan peneliti atau pengamat mengevaluasi tingkat keberhasilan pembelajaran yang telah dilakukan. Pada tahap ini hasil observasi guru dan siswa dianalisa dan dicari kekurangannya.
Data yang dikumpulkan dalam penelitian ini berupa data kualitatif dan kuantitatif. Berikut ini penjabaran mengenai data-data tersebut: 1) Data kualitatif yang dikumpulkan dalam penelitian ini berupa hasil observasi aktivitas guru dan siswa; 2) Data kuantitatif pada penelitian ini berupa hasil nilai belajar siswa pada siklus I dan siklus II. Data tersebut digunakan untuk mengetahui peningkatan hasil belajar setelah diterapkannya strategi time token.

Cara mengumpulkan data dalam penelitian tindakan kelas ini dilaksanakan dengan menggunakan beberapa teknik penelitian yakni observasi untuk siswa dan guru, interview atau wawancara dan tes tulis yang diberikan kepada siswa.

Observasi dalam penelitian tindakan kelas ini dilakukan untuk mengumpulkan data mengenai aktivitas belajar siswa dalam proses pembelajaran dengan menggunakan strategi time token.

Wawancara dalam penelitian tindakan kelas ini dilaksanakan untuk mengumpulkan berbagai data mengenai tingkat keberhasilan siswa pada mata pelajaran IPS dengan menggunakan strategi pembelajaran time token. Narasumber yang diwawancarai yaitu guru yang mengajar IPS di kelas $\mathrm{V}$ dan siswa kelas V.

Alat pengumpulan data dalam penelitian tindakan kelas ini berupa tes tulis atau soal latihan yang diberikan kepada siswa .Tes tulis pada penelitian ini berupa latihan soal IPS materi perjuangan dalam mempersiapkan kemerdekaan Indonesia untuk siswa kelas V sesudah diadakan penelitian 
tindakan kelas. Tes ini digunakan untuk mengetahui peningkatan hasil belajar siswa setelah menerapkan strategi pembelajaran time token.

\section{Hasil}

Data dalam hasil penelitian tindakan kelas ini diperoleh dengan menggunakan beberapa teknik pengumpulan data yaitu observasi untuk siswa dan guru, interview atau wawancara untuk siswa dan guru, serta tes tulis yang diberikan kepada siswa.

Observasi dilakukan untuk mengamati aktivitas guru dan aktivitas siswa kelas $\mathrm{V}$ saat melaksanakan kegiatan pembelajaran IPS materi peristiwa sekitar proklamasi dengan menggunakan strategi time token. Wawancara untuk guru dan siswa dilaksanakan sebelum dan sesudah pembelajaran dengan menggunakan strategi time token.

Selain menggunakan teknik pengumpulan data dengan cara observasi dan wawancara, pengumpulan data juga dilakukan melalui penilaian tes tulis. Penilaian ini digunakan untuk mengetahui sejauh mana peningkatan hasil belajar siswa pada siklus I dan II.

Penyajian data pada penelitian ini akan membagi menjadi dua bagian tahapan pelaporan, yaitu pada: Tahap siklus I dan Tahap siklus II.

Pada pembelajaran pada siklus I diperoleh hasil observasi aktivitas siswa sebesar 27 sedangkan skor maksimalnya adalah 40 , jadi persentasenya adalah $61 \%$ yang berarti aktivitas siswa selama kegiatan pembelajaran berada dalam kategori cukup baik.

Selain itu pada hasil observasi aktivitas guru dapat disimpulkan bahwa dalam kegiatan belajar mengajar pada siklus I, ketrampilan yang dimiliki guru dalam mengajar mendapat jumlah skor 23 dari jumlah skor maksimal 32. Dengan demikian persentasenya adalah $72 \%$ yang berarti aktivitas guru selama kegiatan pembelajaran dalam kategori baik.

Pada hasil nilai belajar siswa yang dicapai belum tuntas karena siswa yang memperoleh nilai $\geq 75$ hanya sebesar $64 \%$ lebih kecil dari persentase ketuntasan yang dikehendaki yaitu sebesar 90\%. Dari perolehan persentase ketuntasan belajar tersebut, maka kemampuan siswa pada mata pelajaran IPS materi peristiwa sekitar proklamasi masih dikategorikan cukup baik.

Setelah mengetahui hasil dari pelaksanaan pada siklus I, nilai persentase ketuntasan yang diperoleh oleh siswa sebesar 64\% masih kurang dari nilai persentase yang diharapkan yaitu sebesar 90\%. Selain itu mempertimbangkan nilai observasi aktivitas guru dan siswa, maka masih perlu untuk melakukan tindakan perbaikan, yaitu melakukan tindakan siklus II. Pada siklus II diharapkan dapat memperbaiki kekurangan-kekurangan yang terjadi pada siklus I, sehingga hasil siklus II diharapkan akan menjadi lebih baik dan mencapai nilai persentase yang diharapkan.

Setelah melaksanakan siklus II, jumlah skor yang diperoleh adalah 32 sedangkan 
skor maksimalnya adalah 40, sehingga setelah dilakukan perhitungan persentase yang diperoleh adalah $80 \%$ yang berarti aktivitas siswa selama kegiatan pembelajaran berada dalam kategori sangat baik. Persentase observasi aktivitas siswa mengalami peningkatan dari siklus I yang sebesar $61 \%$ menjadi $80 \%$ pada siklus II.

Pada hasil observasi aktivitas guru dalam pembelajaran siklus II, ketrampilan yang dimiliki guru dalam mengajar mendapat skor 29 dari skor maksimal 32. Dengan demikian persentasenya adalah $91 \%$ yang berarti aktivitas guru selama kegiatan pembelajaran dalam kategori sangat baik. Persentase ini mengalami peningkatan pada siklus I dari $72 \%$ menjadi $91 \%$.

Pada siklus II nilai siswa juga mengalami peningkatan sebesar 91\%. Persentase ini lebih besar dari persentase ketuntasan yang dikehendaki yaitu 90\%. Dari perolehan persentase ketuntasan belajar tersebut menunjukkan bahwa kemampuan siswa pada mata pelajaran IPS materi peristiwa sekitar proklamasi sudah dikategorikan sangat baik.

Adanya peningkatan aktivitas siswa dan guru pada siklus I dan II dapat dilihat dalam tabel dan diagram di bawah ini.

\begin{tabular}{|c|c|c|l|}
\hline $\begin{array}{c}\text { Aspek } \\
\text { Peningkatan }\end{array}$ & $\begin{array}{c}\text { Siklus } \\
\text { I }\end{array}$ & $\begin{array}{c}\text { Siklus } \\
\text { II }\end{array}$ & Keterangan \\
\hline $\begin{array}{l}\text { Perolehan } \\
\text { skor hasil } \\
\text { observasi }\end{array}$ & 27 & 32 & Meningkat \\
\hline
\end{tabular}

Tabel 1 Perbandingan aktivitas siswa pada siklus I dan Siklus II

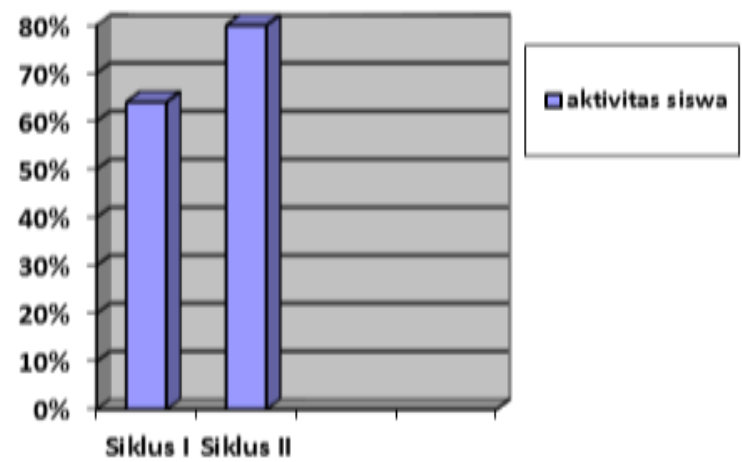

Diagram 1. Persentase aktivitas siswa pada siklus I dan Siklus II

\begin{tabular}{|c|c|c|c|}
\hline $\begin{array}{c}\text { Aspek } \\
\text { Peningkatan }\end{array}$ & $\begin{array}{c}\text { Siklus } \\
\text { I }\end{array}$ & $\begin{array}{c}\text { Siklus } \\
\text { II }\end{array}$ & Keterangan \\
\hline $\begin{array}{l}\text { Perolehan } \\
\text { skor hasil } \\
\text { observasi }\end{array}$ & 23 & 29 & Meningkat \\
\hline
\end{tabular}

Tabel 2 Perbandingan aktivitas guru pada siklus I dan Siklus II

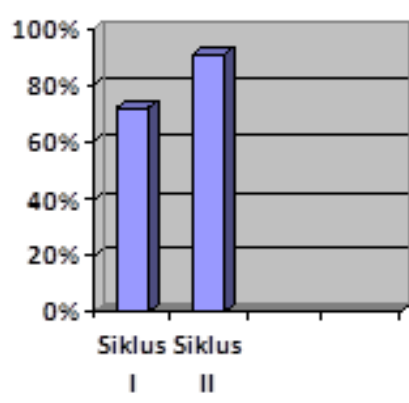

$\square$ Aktivitas guru

Diagram 2 Persentase aktivitas guru pada siklus I dan Siklus II

\begin{tabular}{|l|c|c|c|}
\hline $\begin{array}{c}\text { Aspek } \\
\text { Peningkatan }\end{array}$ & Siklus I & $\begin{array}{c}\text { Siklus } \\
\text { II }\end{array}$ & Keterangan \\
\hline $\begin{array}{l}\text { Perolehan } \\
\text { rata-rata } \\
\text { nilai siswa }\end{array}$ & 72 & 83 & Meningkat \\
\hline
\end{tabular}

Tabel 3 Perbandingan rata-rata nilai siswa pada siklus I dan Siklus II 


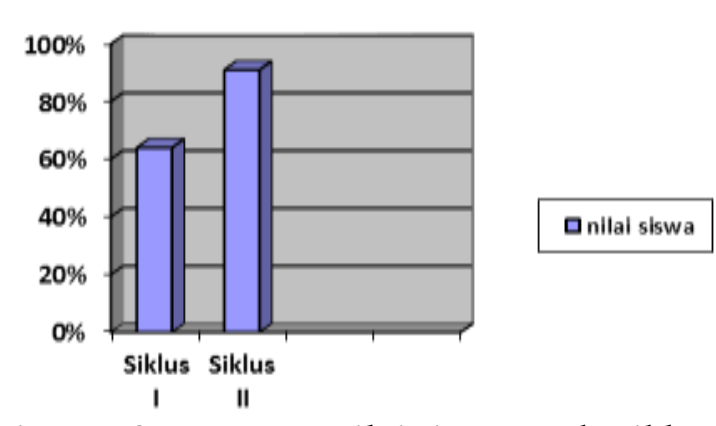

Diagram 3 Persentase nilai sisswa pada siklus I dan II

Melihat dari hasil observasi aktivitas siswa dan guru yang sudah dijelaskan di atas, dapat dikatakan penerapan strategi time token cukup baik. Hal ini ditunjukkan dari hasil tes formatif yang diberikan kepada siswa. Dari siklus I sebesar 64\% meningkat menjadi 91\% pada siklus II.

Berdasarkan hasil observasi pembelajaran, juga terjadi peningkatan dari siklus I ke siklus II. Pada siklus 1, guru tidak sepenuhnya melaksanakan pembelajaran sesuai RPP sehingga persentase kemampuan mengajar guru sebesar $72 \%$. Persentase tersebut sudah tergolong baik, tapi masih perlu ditingkatkan lagi.

Pada siklus II, guru melaksanakan pembelajaran sesuai RPP seingga persentase kemampuan mengajar guru meningkat sebesar 91\%. Persentase tersebut sudah tergolong sangat baik, dan guru perlu memperta-hankannya untuk meningkatkan prestasi belajar siswa.

Aktivitas siswa dalam pembelajaran dengan menerapkan strategi time token, pada siklus I sudah cukup baik, walaupun masih ada beberapa anak yang kurang memperhatikan ketika pembelajaran. Hal ini bisa dilihat pada lembar observasi siswa yang menunjukkan ada 2 siswa yang sangat baik, 4 siswa yang baik, 4 siswa yang cukup baik dan 1 siswa yang kurang baik dalam proses pembelajaran. Jadi persentase aktivitas siswa dalam pembelajaran yaitu Sangat baik sebesar $18,18 \%$, Baik dan cukup baik sebesar $36,36 \%$ sedangkan yang kurang baik hanya $9,09 \%$.

Pada siklus II aktivitas siswa dalam pembelajaran lebih baik daripada siklus I. Jika pada siklus I masih ada siswa yang kurang, maka pada siklus II, semua siswa sudah melaksanakan pembelajaran dengan baik. Hal ini bisa dilihat pada lembar observasi siswa yang menunjukkan ada 6 siswa yang sangat baik, 4 siswa yang baik dan 1 siswa yang cukup baik proses pembelajaran. Jadi persentase aktivitas siswa dalam pembelajaran yaitu Sangat baik sebesar 55\%, Baik sebesar 36\% dan yang cukup baik sebesar $9,09 \%$.

\section{Kesimpulan}

Berdasarkan hasil penelitian tindakan kelas yang dilaksanakan dalam dua siklus di kelas V MI Miftahul Huda pada mata pelajaran IPS, dapat disimpulkan bahwa; 1) Proses pembelajaran dengan penerapkan metode pembelajaran time token berlangsung dengan baik, hal ini terlihat pada proses observasi guru dalam kegiatan pembelajaran pada siklus I sebesar $72 \%$ sudah dalam kategori cukup baik dan mengalami peningkatan pada siklus II sebesar 91\% dalam kategori sangat baik. 
Selain itu dilihat dari hasil observasi aktivitas siswa pada siklus I masih mendapat jumlah skor 27 dari skor maksimalnya 40, sehingga persentase yang diperoleh adalah 64\%, hasil ini mengalami peningkatan pada siklus II hasil observasi aktivitas siswa sudah mendapat jumlah skor 32 dari skor maksimalnya 40, sehingga persentase yang diperoleh adalah $80 \%$, sehingga dapat dikatakan juga mengalami peningkatan. 2) Penerapan strategi time token dapat meningkatan hasil belajar siswa kelas V MI Miftahul Huda pada mata pelajaran IPS. Hal ini dapat dilihat dari siklus 1 dengan nilai rata-ratanya yaitu 72 dan persentase ketuntasan pada siklus I sebesar 64\% dengan 7 siswa tuntas dan 4 siswa tidak tuntas. Hasil nilai siswa tersebut cukup baik tetapi masih perlu diadakan perbaikan karena belum memenuhi kriteria ketuntasan.

Kemudian pada siklus II mengalami peningkatan. Persentase ketuntasan meningkat menjadi 83. Sedangkan persentase ketuntasan pada siklus I yang sebesar $64 \%$ dengan 7 siswa tuntas dan 4 siswa tidak tuntas. Pada siklus II persentase ketuntasan meningkat menjadi sebesar 91\% dengan 10 siswa tuntas dan 1 siswa tidak tuntas.

Dari hasil penelitian tindakan kelas dengan menerapkan strategi time token yang telah dilaksanakan, agar proses pembelajaran selanjutnya bisa berjalan lebih baik dan lebih meningkatkan hasil belajar serta prestasi peserta didik, maka untuk melaksanakan pembelajaran dengan menerapkan strategi time token memerlukan persiapan yang baik, sehingga guru harus mampu membuat perencanaan pembelajaran dan media kupon berbicara yang bisa meningkatkan semangat belajar siswa. Selain itu, sebelum proses perencanaan guru juga harus bisa memilih materi dan mata pelajaran yang tepat dengan strategi ini agar pembelajaran berlangsung dan mendapat hasil yang maksimal.

Dalam rangka meningkatkan prestasi belajar siswa, guru hendaknya lebih sering menggunakan berbagai macam strategi, metode maupun media pembelajaran pada pembelajaran. Perlu adanya penelitian yang lebih lanjut, karena hasil penelitian ini hanya dilakukan di MI Miftahul Huda Lamongan. Untuk penelitian yang serupa hendaknya dilakukan perbaikan-perbaikan agar diperoleh hasil yang lebih baik.

\section{Daftar Pustaka}

Aqib, Zainal. 2013. Model-model, Media dan Strategi Pembelajaran Kontekstual inovatif. Bandung: Yrama Widya

Daryanto, 2013. Strategi dan Tahapan Mengajar. Bandung:Yrama Widya

Hamdani. 2011. Strategi Belajar Mengajar. Bandung: CV Pustaka Setia.

Hamruni, 2012. Strategi Pembelajaran. Yogyakarta: Insan Madani

Huda, Miftahul. 2013. Model-model Pengajaran dan Pembelajaran. Yogyakarta: Pustaka Pelajar

Kunandar, 2011. Langkah-langkah Penelitian Tindakan Kelas. Jakarta: Raja Grafindo Persada.

Sanjaya, Wina. 2006. Strategi Pembelajaran

Berorientasi pada standar proses pendidikan. Jakarta: Kencana

Sanjaya, Wina. 2013. Penelitian Pendidikan. Jakarta:Kencana 
Solihatin, Etin. 2007. Cooperative Learning.

Jakarta: Bumi Aksara

Susanto,Ahmad. 2013. Teori belajar dan

pembelajaran di sekolah dasar. Jakarta:

Kencana

Trianto, 2010. Model Pembelajaran Terpadu.

Jakarta: Bumi Aksara 
